\title{
Axin: A Master Scaffold for Multiple Signaling Pathways
}

\author{
Wen Luo Sheng-Cai Lin \\ Department of Biochemistry, Hong Kong University of Science and Technology, Hong Kong, and \\ Department of Biology, Xiamen University, Xiamen, China
}

\section{Key Words}

Axin, biological function - Axin, identification - Axin/JNK signaling pathway $\cdot$ Wnt pathway

\begin{abstract}
Axin was originally identified from the characterization of the Fused locus, the disruption of which leads to duplication of axis and embryonic lethality. It is a multidomain protein that interacts with multiple proteins and functions as a negative regulator of Wnt signaling by downregulating the $\beta$-catenin levels. Recently, it was demonstrated that Axin also plays an important role in a JNK signaling pathway. Axin utilizes discriminatory domains for its distinct roles in the Wnt pathway and in the Axin/ JNK pathway. Here we review the data that show how Axin regulates multiple signaling pathways by serving as a scaffold protein, controlling diverse cellular functions in proliferation, fate determination, and suppression of tumorigenesis.
\end{abstract}

Copyright (C) 2004 S. Karger AG, Basel

\section{Introduction}

One fundamental problem in embryonic development is how cell fate determination is achieved which gives rise to cell polarity and dorsoventral and anteroposterior specification. Studies of the Wnt signaling pathways have pro- vided much information on how such developmental processes are regulated $[1,2]$. Scaffold proteins serve as vital mediators for cellular signaling. They play architectural roles in integrating incoming signals to downstream effectors which in turn manifest biological functions. Axin, named for its inhibitory role of axis specification in vertebrates, has emerged as a major scaffold protein for regulating a variety of signaling pathways and biological functions. In Wnt signaling, Axin binds to many components in the pathway, including the Wnt coreceptor LRP (lowdensity lipoprotein related protein receptor) [3-5], Dishevelled or Dvl [6, 7], tumor suppressor adenomatous polyposis coli (APC), GSK-3 $\beta$, $\beta$-catenin [8-10], casein kinases [11], protein phosphatase 2A (PP2A) [12], Diversin [13], Ccd1 [14], and Axam [15]. Interestingly, Axin itself is regulated with its stability being modulated by Wnt receptors [5], Dvl [16], and phosphorylation by GSK-3 $\beta$ [17]. In addition, Axin also interacts with proteins that have no close relevance to Wnt signaling, including MAP kinase kinase kinases (MEKK) [18, 19], I-MFA [20], DCAP [21], SH2/3 adaptor protein Grb4 [22], and Smad3 [23]. Interaction of Axin with MEKK leads to JNK activation, proceeding through a cascade from Axin, MEKK, and MKK to JNK. The most intriguing aspect of JNK activation by Axin is that multiple seemingly concrete structural elements of Axin are required [18, 19, 24-27]. Our current review will focus on the Axin-interacting proteins and their functional roles in the Wnt and Axin/JNK pathways.

\begin{tabular}{ll}
\hline KARGER & @ 2004 S. Karger AG, Basel \\
Fax +4161306 12 34 & 1424-862X/04/0133-0099\$21.00/0 \\
$\begin{array}{l}\text { E-Mail karger@karger.ch } \\
\text { www.karger.com }\end{array}$ & $\begin{array}{l}\text { Accessible online at: } \\
\text { www.karger.com/nsg }\end{array}$
\end{tabular}

Sheng-Cai Lin
Department of Biochemistry, Hong Kong University of Science and Technology
Clear Water Bay, Kowloon
Hong Kong (China)
Tel. +852 2358 7294, E-Mail linsc@ust.hk 
Table 1. Axin-interacting proteins and their functions in Axin-mediated signaling

\begin{tabular}{|c|c|c|c|}
\hline Protein & 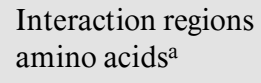 & Function related to Axin & References \\
\hline APC & $89-216$ & APC complexes with Axin to downregulate $\beta$-catenin & $\begin{array}{l}8-10,39 \\
40,68-75\end{array}$ \\
\hline Axam & $507-712$ & $\begin{array}{l}\text { Axam downregulates } \beta \text {-catenin by its desumoylation } \\
\text { activity }\end{array}$ & 15,116 \\
\hline Axin & $757-820$ & $\begin{array}{l}\text { Axin forms homodimer/oligomer via the DIX domain } \\
\text { which is necessary for JNK activation }\end{array}$ & 12,18 \\
\hline$\beta$-Catenin & $437-506$ & $\begin{array}{l}\text { Axin serves as a platform for APC, GSK- } 3 \beta \text { and } \beta \text {-catenin } \\
\text { to enhance } \beta \text {-catenin degradation }\end{array}$ & $\begin{array}{l}38,81 \\
90-96\end{array}$ \\
\hline Ccd 1 & Not determined & $\begin{array}{l}\text { Ccd } 1 \text { acts as a positive regulator for Wnt signaling by } \\
\text { interacting with Axin, presumably via its DIX domain }\end{array}$ & 14 \\
\hline CKI & $217-352 / 508-712$ & $\begin{array}{l}\text { CKI } \varepsilon \text { enhances FRAT-GSK- } 3 \beta \text { interaction and stabilizes } \\
\beta \text {-catenin by reducing phosphorylation; } \\
\text { CKI } \alpha \text { enhances } \beta \text {-catenin degradation as a priming kinase } \\
\text { for GSK- } 3 \beta \text {; } \\
\text { both CKI } \varepsilon \text { and CKI } \alpha \text { inhibit Axin-mediated JNK } \\
\text { activation by competing against MEKK1 binding }\end{array}$ & $\begin{array}{l}24,11,26 \\
81 \\
109-112\end{array}$ \\
\hline DCAP & Pro-rich motifs & Axin may regulate DCAP in glucose transport & 133 \\
\hline Diversin & $353-437$ & $\begin{array}{l}\text { Diversin is reportedly able to recruit CKIE to the Axin/ } \\
\text { GSK- } 3 \beta \text { complex; it is also involved in JNK activation }\end{array}$ & 13 \\
\hline Dvl & $530-712 / 757-820$ & $\begin{array}{l}\text { Dvl inhibits phosphorylation of Axin by GSK- } 3 \beta \text { and } \\
\text { inhibits Axin-promoted GSK- } 3 \beta \text { phosphorylation of } \\
\beta \text {-catenin }\end{array}$ & $6,7,110$ \\
\hline Grb4 & Not determined & Unknown & 22 \\
\hline GSK-3 $\beta$ & $353-437$ & $\begin{array}{l}\text { GSK- } 3 \beta \text { complexes with Axin to facilitate its } \\
\text { phosphorylation of } \beta \text {-catenin, regulates Axin stability } \\
\text { via phosphorylation, and inhibits JNK activation of } \\
\text { Axin by preventing MEKK1 binding to Axin }\end{array}$ & $\begin{array}{l}24,17,38 \\
77-81\end{array}$ \\
\hline I-mfa & $385-468$ & $\begin{array}{l}\text { It inhibits Axin-mediated downregulation of } \beta \text {-catenin } \\
\text { and JNK activation }\end{array}$ & 20 \\
\hline LRP & $353-437$ & $\begin{array}{l}\text { LRP5, } 6 \text { recruit Axin to the membrane, leading to } \\
\text { degradation of Axin }\end{array}$ & $3-5$ \\
\hline MEKK1 & $217-352$ & It mediates JNK activation by Axin & 18 \\
\hline MEKK4 & $678-712$ & It mediates JNK activation by Axin & 19 \\
\hline PIAS & $687-832$ & It mediates Axin sumoylation and JNK activation & 27 \\
\hline PP2A & $298-506 / 508-712$ & It interacts with Axin and enhances $\beta$-catenin degradation & $12,97-102$ \\
\hline Smad3 & $508-713$ & $\begin{array}{l}\text { Axin facilitates activation of Smad } 3 \text { by TGF- } \beta \text { receptors } \\
\text { for efficient TGF- } \beta \text { signaling }\end{array}$ & 23 \\
\hline
\end{tabular}

a All amino acid positions are according to the mouse short form of axin (1-832).

\section{Identification of Axin}

Axin, the product of the mouse Fused (Fu) gene, was originally identified as an inhibitor of the Wnt-signaling pathway in that it regulates embryonic axis formation [28]. The mouse Fused locus was identified 66 years ago, mutation of which manifests as dominant kinky-tail phenotype. Homozygotes of the original Fused allele sometimes display deafness and neurological and urogenital defects, in addition to the kinked tail [29]. The phenotypic variation among $F u$ mice is a complicated phenomenon due to epigenetic factors inherently determined by the nature of the $F u$ mutation caused by an intracisternal A particle (IAP) element [30-32]. The IAP element is a member of the abundant family of murine transposable elements. The insertion begins $35 \mathrm{bp}$ downstream of exon 6 , within intron 6 of the Axin gene. Subsequently, two other $F u$ alleles were identified, $F u^{k i n k y}\left(F u^{k i}\right)$ and $F u^{k n o b b y}$ 


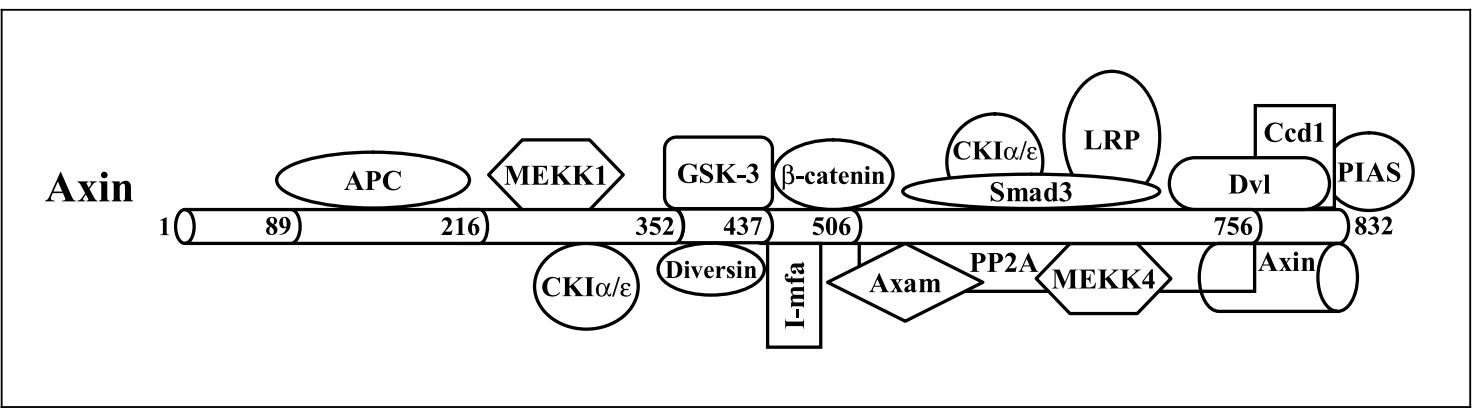

Fig. 1. Axin is a multidomain protein and binds to a wide array of proteins. Shown here are the Axin-interacting proteins with known relative binding positions in Axin. Of special note, CK1 $\alpha / \varepsilon$ seems to also require the MEKK1binding region, in addition to the sequence in the PP2A-binding region, for maximal binding affinity. MEKK1 and MEKK4 bind to two distinct regions, although they share sequence similarity.

$\left(F u^{k b}\right)[33,34]$. Whereas, the $F u^{k i}$ allele is apparently extinct, the $F u^{k b}$ allele is known to also carry an IAP insertion inside exon 7. Mice with $F u^{k i}$ or $F u^{k b}$ allelic mutation exhibit more severe phenotypes than the original $F u$ mutant mice. While heterozygotes of $F u^{k i}$ and $F u^{k b}$ mice share the kinked-tail phenotype as $F u$ mice, homozygotes die prenatally between 8 and 10 days postcoital. More importantly, these homozygotic embryos show complete or partial duplication of axial structures, neural tube malformation, and outgrowth of ectoderm, suggesting that the gene encoded by the Fused locus plays a critical role in axis formation [33, 34]. A fourth allele of $F u$ was more recently identified based on its failure to rescue the embryonic lethality of $F u^{k b}$ which is named $F u^{T g l}$ as a transgenic insertion into the Fused gene [35]. While heterozygotes of $F u^{T g l}$ display tail kinking, homozygous embryos exhibit phenotypes identical to those of embryos with $F u^{k i}$ or $F u^{k b}$ mutations. Aided by the DNA sequence provided by the transgene insertion, the $F u$ gene was cloned by F. Costantini and his coworkers [28]. It was revealed that the mouse $F u$ gene encodes a protein of 832 amino acids in size and was renamed Axin for axis inhibition. Most noticeably, Axin contains an RGS domain conserved in the large protein family regulators of $G$ protein signaling or RGS proteins [36, 37]. It should be pointed out that the RGS domain in Axin is divergent enough not to bind $\mathrm{G} \alpha$ subunits [our unpubl. data].

Soon after the cloning of Axin from the analysis of the Fused locus, Axin was independently identified as a protein that binds to GSK-3 $\beta$, based on a yeast two-hybrid screening of a rat brain cDNA library [38]. In the same screening, an Axin homologue, Axil (Axin-like, also known as Axin2 or conductin), that shares $44 \%$ identity with Axin, was also identified [39] and shown to interact with both GSK-3 $\beta$ and $\beta$-catenin and to inhibit Wnt signaling. Almost simultaneously, Axin $2 /$ conductin was also identified by a yeast two-hybrid screen, using $\beta$-catenin as bait [40]. The Axin gene is conserved in humans, rats, mice, chickens, Xenopus, and Drosophila [28, 38, 41, 42]. More recently, an Axin-like protein, termed PRY-1, has also been identified in Caenorhabditis elegans and demonstrated to be a functional homologue of Axin [43]. Axin is expressed widespread among tissues, consistent with its diverse roles in controlling development as well as tumorigenesis.

The mouse Axin protein has 832 amino acid residues in size. It must be noted here that there is a confusion in the literature regarding the numbering of amino acids of the mouse Axin due to the initial caution that the cloned cDNA for Axin might not be of full length, and the potential 124 codons in the $5^{\prime}$ mRNA region were counted as aa 1-124. However, there is a longer form derived from alternative splicing which is identical to the short form, except for an insertion of 36 amino acids at position 735 , encoded by exon 6 [28]. It has now become clear that Axin is a multidomain protein that binds to a great number of proteins, including well-documented components of the Wnt signaling pathways and factors that have no apparent relation to Wnt signaling (see table 1 and fig. 1 and 2).

\section{Biological Functions of Axin}

\section{Regulation of Axis Formation}

Axin was initially cloned from the analysis of the Fused locus, in which mutations cause defects in axis formation [28]. An intriguing feature of many homozygous Axin 


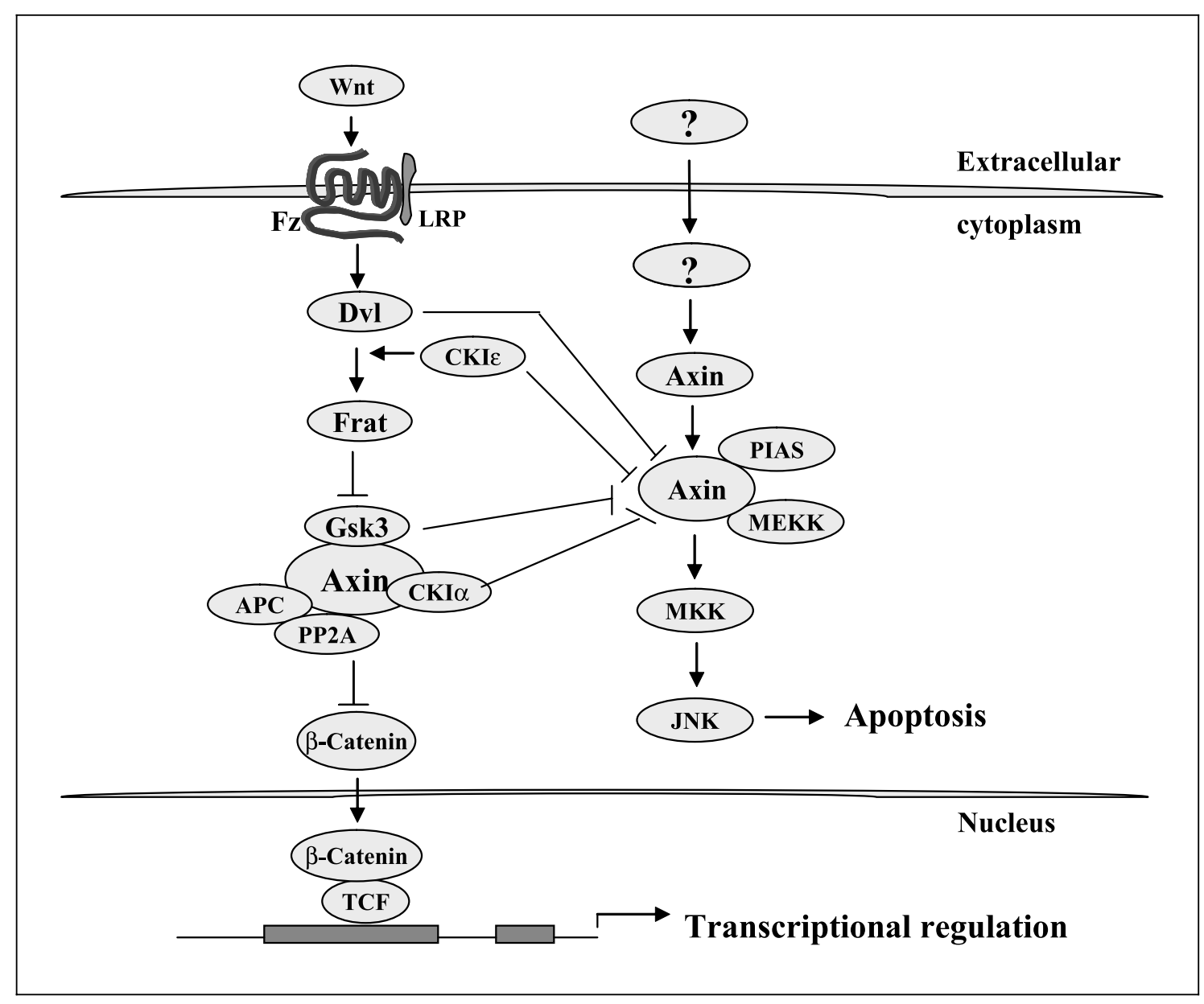

Fig. 2. Axin serves as a scaffold for $\beta$-catenin degradation in the absence of Wnt signaling. APC, GSK-3 $\beta$, CKI $\alpha$, and PP2A are the major factors that facilitate $\beta$-catenin degradation. When Wnt signaling is initiated via Frizzled and LRP, activated Dvl with the help of CKI $\varepsilon$ increases FRAT binding to GSK-3 $\beta$ and destabilizes AxinPP2A affinity, thereby decreasing $\beta$-catenin phosphorylation and subsequent degradation. The accumulated $\beta$-catenin is then translocated into the nucleus, where it binds and activates other transcription factors such as TCF, regulating expression of a variety of target genes. In parallel, Axin is also a scaffolding protein for MEKK1/4 in the Axin/JNK pathway. Interaction of MEKK1/4 leads to JNK activation via MKK4/7, in which PIAS binding to the extreme C terminus of Axin plays an integral part. In contrast, Dvl and CKI $\alpha / \varepsilon$ inhibit JNK activation by Axin, with Dvl interfering with Axin homodimerization and CKI $\alpha / \varepsilon$ preventing MEKK binding. Overexpression of Axin leads to apoptosis in some cells which depends on Axin's ability to activate JNK. mutant embryos is a duplication of the embryonic axis $[33,34]$, suggesting that Axin normally plays a negative regulatory role in the response to an axis-inducing signal. Indeed, when Axin is injected into Xenopus embryos, most of them develop with strong axial defects [28]. Coexpression of Axin inhibits the induction of the secondary dorsal axis by Wnt, Dvl, and kinase-negative GSK-3, while it does not affect $\beta$-catenin- and Siamois-induced secondary axis formation [28]. Although injection of Noggin or dominant-negative bone morphogenetic protein receptor also causes secondary axis formation, Axin fails to block this induction [28]. These results indicate that Axin exerts its function on axis formation by specifically inhibiting the Wnt signaling pathway.

\section{Axin as a Tumor Suppressor}

As Axin has the ability to downregulate $\beta$-catenin protein levels, it can be regarded as a tumor suppressor [44]. A plethora of in vitro and in vivo studies performed in Xenopus, Drosophila, and cultured mammalian cells has 
demonstrated that Axin is central to the downregulation of $\beta$-catenin [7, 9, 10, 28, 38, 40, 41, 45-48]. It is not entirely clear how Axin functions, but it has been proposed to facilitate the phosphorylation of $\beta$-catenin and APC by GSK-3 $\beta[9,38]$. Thus Axin could be viewed as a tumor suppressor based on its ability to downregulate Wnt signaling, and this has now been verified by documentation of its biallelic inactivation in human hepatocellular cancers and cell lines [49-51]. Importantly, these mutations were identified in those hepatocellular carcinomas that lacked activating mutations in the $\beta$-catenin gene (CTNNb1). All of the mutations were predicted to truncate the Axin protein in a manner that eliminated the $\beta$-catenin-binding sites [49]. Reintroduction of wild-type Axin into hepatocellular carcinoma cells leads to apoptosis in these cells. The notion of Axin being a tumor suppressor was further underscored by the findings that overexpression of Axin in $\mathrm{CHO}$ cells results in apoptosis [52] and that induced overexpression in transgenic mice leads to massive cell death in different organs [53]. It should be noted that Axin-induced apoptosis in $\mathrm{CHO}$ cells depends on Axin's ability to downregulate $\beta$-catenin [52], again confirming the determining role of $\beta$-catenin in promoting cell growth/survival.

Similarly, sequence variants of the Axin gene (AXIN1) were found in breast, colon, and other cancers. These variants interfered with Axin and GSK3 binding [54, 55]. Using single-strand conformation polymorphism analysis, many amino acid alterations have been detected in AXIN1 [56-58]. Therefore, it is evident that Axin mutation is relatively common in cancers. However, in most cases, it remains to be determined whether these cancers contain simultaneous mutations in genes encoding other Wnt components.

\section{Role in Cytoskeleton Rearrangement}

Dishevelled (Dvl or Dsh) signals downstream of Wnt receptors and stabilizes $\beta$-catenin in Wnt signaling pathway [44]. It was reported that Dvl contributes to cytoskeletal reorganization during gastrulation [59-61] and mitotic spindle orientation during asymmetric cell division [62]. Both Dvl and Axin contain a conserved 85-residue module of unknown structure and biological function called the DIX domain [63]. Recently, it was demonstrated by using nuclear magnetic resonance spectroscopy that the DIX domain mediates targeting Dvl to actin stress fibers and cytoplasmic vesicles in vivo [64]. An attractive hypothesis is that Axin could also mediate cytoskeleton rearrangement via the DIX domain. Furthermore, the recent finding that Axin interacts with
Grb4, an SH2/3 domain adaptor protein that plays a role in Eph/ephrin signaling that controls cell and axon growth-cone movement [22], also suggests that Axin may have a function in cytoskeleton rearrangement.

\section{Mutation of Axin Leads to Neurological Defects}

In addition to their effects on axis formation, Axin mutations cause neuroectodermal defects (incomplete closure, malformation or truncation of the head folds). It remains to be determined whether these abnormalities are also due to defective regulation of Wnt signaling pathways. Anterior truncations have been observed in transgenic mouse embryos that ubiquitously expressed Cwnt8C and in frog embryos ectopically expressing Xwnt-8 after midblastula transition [65]. Therefore, inappropriate Wnt signaling may also account for the neuroectodermal defects in Axin mutant embryos. Another interesting question that can now be addressed is the molecular basis of the dominant defects seen in $\operatorname{Axin}^{F u}, A x i n^{K b}$, and $A x i n^{K i}$ heterozygotes which were attributed to gain-offunction mutations [66]. Analysis of $\mathrm{Axin}^{\mathrm{Fu}}$ and $A x i n^{\mathrm{Kb}}$ suggests that their similar dominant effects may be mediated by $\mathrm{C}$-terminally truncated Axin proteins that are potentially encoded by abnormally spliced transcripts. It is possible that these abnormal Axin proteins perturb Wnt signaling pathways involved in brain and skeletal development.

\section{Axin Interacts with Multiple Components in the Wnt Pathway}

Axin possesses multiple functional domains. Of note, it has an RGS domain that is conserved in the protein family of regulators of $\mathrm{G}$ protein signaling, near its $\mathrm{NH} 2$ terminus. At the $\mathrm{C}$ terminus, Axin contains another domain named DIX that is shared by Dishevelled and a recently identified Wnt regulator called Ccd1. In addition, Axin contains numerous domains for interaction with multiple other proteins than APC and Dvl/Ccd 1 that bind to the RGS and to the DIX domain, respectively. This section tries to summarize all the Axin-interacting proteins and their interaction positions on Axin, wherever available.

\section{Adenomatous polyposis coli}

The RGS domain harbors amino acid residues (aa 89216) that are sufficient for APC binding [8]; the crystal structure of an Axin-APC complex reveals that APC interacts with the Axin-RGS domain on a face that is distinct 
from the $G$ protein interface of classical RGS proteins. Those residues in the Axin-RGS domain that contact with APC are not conserved in $\mathrm{G}_{i \alpha}$-binding RGS proteins [67]. Similarly, many of those residues that form contacts with $\mathrm{G}_{\mathrm{i} \alpha}$ seen in RGS4- $\mathrm{G}_{\mathrm{i} \alpha}$ are not conserved in the Axin-RGS domain, consistent with our unpublished observation that Axin does not bind to $\mathrm{G}_{\mathrm{i} \alpha}$ proteins.

APC is a tumor suppressor genetically identified from the analysis of families that had familial APC. Subsequent studies have demonstrated that APC interacts with $\beta$ catenin, downregulating $\beta$-catenin signaling by enhancing degradation and exporting it from the nucleus into the cytoplasm $[68,69]$. Genetic ablation of the Drosophila APC gene $(D-A P C)$ resulted in upregulation of $\beta$-catenin signaling, ultimately confirming that APC is functionally linked with the $\beta$-catenin function [70]. The experiments showed that reduction in the Drosophila $\beta$-catenin, Armadillo, rescues the phenotypic defects in the $D-A P C$ mutant, while Armadillo overexpression mimics D-APC inactivation.

APC requires Axin to downregulate $\beta$-catenin. It was demonstrated that complex formation of APC and Axin facilitates the phosphorylation of $\beta$-catenin by GSK-3 $\beta$ which is followed by degradation of $\beta$-catenin [71]. The sites in APC responsible for binding to Axin and conductin/Axil reside in the 20 amino acid repeats region [40, 72]. The region of APC containing these sites is located just downstream of the mutation cluster region, suggesting that the interaction of APC with Axin and conductin/ Axil is important to its tumor suppressor function. Indeed, a fragment of APC that induces $\beta$-catenin degradation [73] is rendered inactive by disruption of its Axinbinding sites [72]. Also, overexpression of an Axin fragment spanning the RGS domain inhibits APC-mediated $\beta$-catenin degradation. An APC fragment with mutated $\beta$-catenin-binding sites, but intact Axin-binding sites, also fails to induce degradation of $\beta$-catenin. Thus, APC needs to interact directly with both Axin and $\beta$-catenin to efficiently induce the degradation of $\beta$-catenin. On the other hand, Axin mutants lacking the APC-binding domain are still able to degrade $\beta$-catenin when overexpressed [8-10, $39,74]$ which can be reconciled by the retained binding sites for GSK-3 $\beta$ and CKI $\alpha$ that play primary functions in $\beta$-catenin degradation [75]. However, the fact that $\beta$-catenin is abnormally accumulated in SW480 cells indicates that endogenous expression of Axin is not sufficient to regulate the levels of $\beta$-catenin in the absence of APC. Thus, the associated Axin and APC may be more effective in inducing the degradation of $\beta$-catenin than Axin alone.

\section{$G S K-3 \beta$}

From a yeast two-hybrid screen of a rat brain library using GSK-3 $\beta$ as bait, Axin was identified to be a protein that interacts with GSK-3 [38]. GSK-3 $\beta$ binds to the Axin region of a $353-437$. The crystal structure of GSK-3 $\beta$ in complex with a minimal GSK-3 $\beta$-binding segment of Axin has been determined [76]. It was revealed that the Axin-binding site is colocalized with FRAT-binding site in the C-terminal domain in GSK-3 $\beta$, providing the structural basis for competitive binding of Axin and FRAT to GSK-3 $\beta$ [76].

The serine/threonine kinase GSK-3 $\beta$ (glycogen synthase kinase $3 \beta$ ) is an essential protein kinase that regulates numerous functions within the cell. It was initially isolated as an enzyme that could phosphorylate and inactivate glycogen synthase. The GSK-3 $\beta$ activity influences cellular events ranging from glycogen metabolism, microtubule dynamics, and modulation of transcription factors (NFAT, CREB, $\beta$-catenin, and c-Jun) to axis development [77-79]. In Wnt signaling, it is an instrumental enzyme that phosphorylates $\beta$-catenin which is an a priori step for $\beta$-catenin degradation or downregulation. Failure of GSK-3 $\beta$ to bind $\beta$-catenin results in dysregulation of $\beta$ catenin and leads to cancer. Normally, a small portion of GSK-3 $\beta$ translocates to the nucleus during the $\mathrm{S}$ phase, although the function of this relocation is unknown. However, in the cancers PEL (primary effusion lymphoma) and KS (Kaposi's sarcoma), the latency-associated nuclear antigen (LANA), which possesses sequences with homology to the Axin GSK-3 $\beta$-binding domain, traps GSK-3 $\beta$ into the nucleus and thus results in the depletion of cytoplasmic GSK-3 $\beta$, leading to stabilization of $\beta$-catenin and downstream TCF- and LEF-mediated transcriptional responses [80]. One unique feature of GSK-3 $\beta$ phosphorylation of its substrates is that it requires a priming phosphorylation on a separate site by casein kinase I $\alpha$ $(\mathrm{CKI} \alpha)$ and hence couple casein kinase for its function to downregulate $\beta$-catenin [81].

GSK-3 $\beta$, in addition to using Axin as a scaffold to facilitate its phosphorylation of $\beta$-catenin, it may well be a kinase that regulates Axin stability via phosphorylation. Axin harbors several possible GSK-3 $\beta$ phosphorylation sites: SANDSEQQ $S^{330}, S D A D T L S L T^{341}$, and $S$ LTD $S^{343}$; when these serine or threonine sites are mutated to alanine, the levels of Axin phosphorylation are reduced. Treatment of cells with $\mathrm{LiCl}$, a GSK-3 $\beta$ inhibitor, decreases the protein stability of Axin, while the phosphatase inhibitor okadaic acid reverses the effect of $\mathrm{LiCl}$, indicating that phosphorylated Axin is more stable than its unphosphorylated form [17]. 


\section{$\beta$-Catenin}

$\beta$-Catenin was originally identified as a protein that interacts with the cytoplasmic domain of cadherin and links cadherin to $\alpha$-catenin which in turn mediates the anchorage of the cadherin complex to the cortical actin cytoskeleton $[82,83]$. $\beta$-Catenin can exist inside the cell in multiple pools: most notably one fraction is bound to the cadherin cytoplasmic tail at the plasma membrane and participates in cell adhesion, the other fraction is in complex with LEF/TCF transcription factors mediating transcriptional regulation [84-86]. Genetic studies in Drosophila have demonstrated that $\beta$-catenin/Armadillo is a critical element in the Wnt pathway [87]. In fact, gainof-function or loss-of-function of components in the canonical Wnt pathway results in upregulation or downregulation of $\beta$-catenin, respectively, pointing to it as a common denominator for Wnt signaling $[88,89]$. $\beta$-Catenin is peculiar in that it seems to be both a skeletal factor and a signaling-regulated transcription cofactor. It serves as a relay step to integrate extracellular signals into the transcriptional events.

Axin (aa 437-506) interacts directly with the region containing Armadillo repeats $2-7$ of $\beta$-catenin [38]. This region of Axin is adjacent to its GSK-3 $\beta$-binding site. GSK- $3 \beta$ and $\beta$-catenin could bind simultaneously to Axin, forming a ternary complex. This complex formation enhances phosphorylation of $\beta$-catenin by GSK-3 $\beta$ and CKI $\alpha[38,81]$. Phosphorylated $\beta$-catenin is recognized by $\beta-\operatorname{TrCP}$, a component of an E3 ubiquitin ligase, and is degraded via the ubiquitin-mediated proteosome pathway [90]. Activation of Wnt signaling results in displacement of GSK-3 $\beta$ from the complex by Dishevelled and Frat (GSK-3 $\beta$-binding protein or GBP) and allows accumulation of $\beta$-catenin that enters the nucleus. Inside the nucleus, it complexes with a variety of transcription factors/cofactors to regulate a number of cell growth/cell differentiation related genes including Siamois [91], Twin [92], Xnr-3 [93], Ubx [94], cyclin D1 [95], and c-MYC [96].

\section{Protein Phosphatase $2 A$}

PP2A is an intracellular serine/threonine protein phosphatase. It is a heterotrimeric protein comprising a conserved catalytic subunit (C), a structural subunit (A), and one of variable regulatory (B) subunits. Three unrelated families of PP2A B subunits have been identified, i.e., B, $\mathrm{B} 56$, and PR72. These regulatory $\mathrm{B}$ subunits regulate the subcellular localization and substrate specificity of PP2A. Distinct PP2A heterotrimers dephosphorylate different substrates or different sites on the same substrate [97].
A domain of Axin (aa 508-712) was found to physically interact with the catalytic subunit of PP2A [12, 98]. However, there seems to be another PP2Ac-interacting domain on Axin. In a separate study, PP2A was shown to interact with another domain of Axin (aa 298-506), in addition to the aa 508-712 region. Interestingly, the B56 subunit of PP2A interacts with APC, Dvl, in the AxinGSK3 $\beta-\beta$-catenin complex [97, 99-101], while the C subunit interacts with Axin as mentioned above. Increased expression of B56 decreases the abundance of $\beta$-catenin, thereby reducing $\beta$-catenin signaling. The biochemical role of the interaction between the PP $2 \mathrm{~A} \mathrm{C} / \mathrm{B}$ heterodimer and the $\beta$-catenin degradation complex is unknown. One report shows that PP2A dephosphorylates APC [98]. However, this finding does not seem to address how $\beta$ catenin levels are reduced in cells overexpressing PP2A, as it has been reported that phosphorylation of APC is important for $\beta$-catenin binding and its subsequent degradation [102]. The role of PP2A became more confusing by another finding that the catalytic subunit of PP2A exerts a positive role in Wnt signal transduction [99].

\section{Casein Kinases}

The CKI family of protein kinases is a group of highly related and ubiquitously expressed serine/threonine kinases found in all eukaryotic organisms from Protozoa to man. Recent studies have elucidated diverse roles for CKI in regulating critical processes such as Wnt signaling, circadian rhythm, nuclear import, and Alzheimer's disease progression [103-106]. In Wnt signaling, using expression cloning to identify novel components of the Wnt pathway, two independent groups first identified CKIE, but not CKI $\alpha$, as a positive factor that can mimic wnt in inducing axis duplication in Xenopus [107, 108]. Inhibiting CKIE in $C$. elegans generates worms with a mom phenotype, also indicative of a loss of Wnt signals [107]. CKIE functions downstream of Dvl and upstream of GSK-3 $\beta$ and interacts with Dvl [109]. Biochemically, CKI $\varepsilon$ was shown to phosphorylate multiple components in the $\beta$-catenin degradation complex: APC, Axin, Dvl, and $\beta$-catenin [109]. Most recently, the functional significance of CKIE phosphorylation of Dvl was found to enhance the interaction between Dvl and Frat. The enhanced DvlDFrat interaction presumably causes a conformational change that leads to dissociation of GSK-3 $\beta$ from Axin and recruits it to Frat [110], reducing phosphorylation of $\beta$-catenin by GSK- $3 \beta$, as previously proposed [111]. However, in a separate study, CKIE was found to interact with an ankyrin repeat protein called diversin and facilitates $\beta$-catenin degradation, hence act- 
ing as an inhibitor in canonical Wnt signaling. It is unclear how the discrepancy arose. Future work with more genetic evidence should clear the cloud over the interpretation of the actual role of CKI $\varepsilon$. Nevertheless, the available data appear to be consistent with the view that CKIE and CKI $\delta$ interact directly with Dvl and positively regulate the canonical Wnt pathway by destabilizing the Axin-PP2A complex [109] and stabilizing Frat1 binding to Dvl [110].

CKI $\alpha$ was found also to interact with Axin [24, 26, 81]. Interestingly, unlike $\mathrm{CKI} \varepsilon, \mathrm{CKI} \alpha$ enhances $\beta$-catenin degradation by serving as a priming kinase that phosphorylates $\beta$-catenin on the $\mathrm{C}$-terminal serine residue, for GSK$3 \beta$ to phosphorylate $\mathrm{N}$-terminal serine/threonine residues in the proteosome-mediated degradation of $\beta$-catenin [81]. CKI $\alpha$ seems to bind to two disparate domains of Axin [26], with one in the MEKK1-binding domain and the other in the PP2A-binding region. CKI $\alpha$ constitutively phosphorylates $\beta$-catenin on $S^{45}$ in an unregulated manner, consistent with $\beta$-catenin being degraded constantly in the absence of Wnt signaling [112].

\section{Dishevelled and Ccd1}

The DIX domain (Dishevelled/Axin homologous domain) in Axin is between aa 757 to 820 , twelve residues from the C-terminal end. Axin forms homodimers via its DIX domain [12]. As the name implies, the DIX domain is conserved in Dishevelled (Dvl) [113], and the identity between the DIX domains of Axin and Dvl is 37\%. This similarity raises the possibility that Dvl might also associate with Axin through the DIX domain. Indeed, Kishida et al. [6] reported that Dvl-1 forms a complex with Axin and that the DIX domain of Axin is sufficient for the complex formation of Dvl-1. Experiments with various deletion mutants of GST-Axin indicate that aa 530-712 of Axin are also important for its direct interaction with Dvl-1 [6].

Dvl proteins (Dvl-1-3) are intracellular multimodular factors that positively transduce Wnt signals through interaction with the specific Wnt receptor Frizzleds to inactivate GSK-3 $\beta$ kinase activity. Although the exact mechanism of Dvl inhibition of GSK-3 $\beta$ is not clear, Dvls are known to interact with CKI [107], CKII [114], and GBP/Frat1 [7, 115]. Dvls interact with Axin via their conserved DIX domain, regulating the $\beta$-catenin degradation complex APC/Axin/GSK-3 $\beta / \beta$-catenin/CKI $\alpha$. It is believed that activated Dvls destabilize GSK-3 $\beta$ binding to Axin by virtue of enhancing the GBP/FRAT interaction with GSK-3 $\beta$ [110], attenuating $\beta$-catenin phosphorylation and degradation. It has also been reported that an
$\mathrm{N}$-terminal sequence of Axin could interact with the PDZ domain of Dvl [7].

Recently, based on sequence similarity, another DIXdomain-containing protein has been identified, named Ccd1 for coiled-coil DIX1, from both zebrafish and mouse. Ccd1 forms homodimer and heterodimer with Axin and Dvl. Ccd1 acts as a positive regulator for Wnt signaling, in that it activates TCF-dependent transcription, and its dominant-negative form (DN-ccd1) can rescue phenotypes resulting from overexpression of wnt8 [14].

\section{Axam}

Axam was identified as a novel Axin-binding protein that inhibits the Wnt signaling pathway by downregulating $\beta$-catenin signaling. Expression of various deletion mutants of Axin with Axam in COS cells showed that the region containing residues 507-712 of Axin is mainly responsible for the interaction with Axam [15]. The Cterminal region of Axam has an amino acid sequence similar to that of the catalytic region of SENP1, a SUMOspecific protease. Axam exhibited the activity to remove SUMO from sumoylated proteins in vitro and in intact cells. Neither the Axin-binding domain nor the catalytic domain alone was sufficient for the downregulation of $\beta$ catenin. An Axam fragment that contains both domains was able to decrease the level of $\beta$-catenin. Upon substitution of Ser for $\mathrm{Cys}^{547}$ in the catalytic domain, Axam lost its desumoylation activity and decreased the activity to downregulate $\beta$-catenin. These results demonstrated that Axam functions as a desumoylation enzyme to downregulate $\beta$-catenin and suggested that sumoylation is involved in the regulation of the Wnt signaling pathway [116]. Most recently, Axam has been shown to reduce TCF-4 sumoylation catalyzed by E3 ligase PIASy [117].

\section{Low-Density Lipoprotein Receptor Related Proteins}

The LRPs are structurally similar to those of the LDL receptor gene family that have been considered to be prototypes of cargo receptors for delivery of macromolecules into cells via endocytosis. However, the identification of additional members of the LDL receptor family and the elucidation of their biological functions have revealed that LRPs play diverse biological roles, particularly in cellular signal transduction [118]. LRP5 and LRP6 and their Drosophila homologue Arrow have been implicated in the reception of Wnt signals $[3,4,119,120]$. Arrow acts downstream of Wnt, but upstream of Dvl, and as a membrane protein, it interacts with Frizzleds to initiate signaling [4]. In fact, LRP5,6/Arrow function as coreceptors 
with Frizzled proteins. Wnt provides a bridging function in assembling a complex of Frizzled and LRP6, at least for the particular combination of $\mathrm{mFz} 8 / \mathrm{mWnt}-1 / \mathrm{mLRP} 6$ $[120,121]$.

Axin was shown to interact with the intracellular domain of LRP5, an interaction that is enhanced by Wnt signals [3]. This interaction could cause translocation of Axin to the membrane. Interestingly, the region from the $\mathrm{N}$-terminal to the GSK-33-binding domain of Axin seems to prevent binding with LRP. The molecular/biochemical nature of the Wnt-enhanced Axin-LRP interaction remains to be determined. A recent report demonstrated that the consequence of Arrow-mediated relocation of Axin to the membrane leads to Axin degradation, so that $\beta$-catenin signaling is enhanced [5].

\section{Diversin}

Diversin is a recently reported vertebrate protein that interacts with two components of the canonical Wnt pathway, CKIє and Axin2/Conductin [13]. Diversin is distantly related to Diego of Drosophila which functions in a pathway that controls planar cell polarity. Morpholinobased gene ablation in zebrafish shows that Diversin is crucial for axis formation which depends on $\beta$-catenin signaling. It is shown that Diversin acts as a molecular switch that suppresses Wnt signals mediated by the canonical $\beta$ catenin pathway and stimulates signaling via JNK. It has also been alleged that Diversin recruits CKIs to the $\beta$ catenin degradation complex that consists of Axin/Conductin and GSK-3 $\beta$ and allows efficient phosphorylation of $\beta$-catenin, inhibiting $\beta$-catenin/Tcf signals. However, in another study [81], CKI $\alpha$, but not CKIE, was shown to prime GSK-3 $\beta$ phosphorylation of $\beta$-catenin; it is unclear how the discrepancy arose.

\section{I-mfa}

I-mfa is an inhibitor of myogenic basic-helix-loop-helix transcription factors. It was shown that I-mfa interacted in vivo with the Axin complex through its $\mathrm{C}$-terminal I-mfa domain, and this interaction inhibited Axin-mediated downregulation of free levels of cytosolic $\beta$-catenin. I-mfa was also shown to decrease Axin-mediated JNK activation [20].

\section{Regulation of Axin}

Axin itself seems to be highly regulated, through phosphorylation and intracellular translocation. Wnt signaling induces dephosphorylation of Axin [17, 47]. The dephos- phorylated Axin binds $\beta$-catenin less efficiently than the phosphorylated form. Thus, Wnt-induced dephosphorylation may be important to prevent the phosphorylation of $\beta$-catenin by GSK-3 $\beta$, so that $\beta$-catenin can accumulate to high levels and activate transcription in concert with TCF/LEF. A recent study provided strong evidence, in transgenic flies that express a fusion protein of the cytoplasmic domain of Arrow/LRP5/6 linked to the C-terminal of the Wnt receptor Frizzled-2, that Wnt signaling is regulated by the levels of Axin protein [5]. The physical proximity of LRP to the Wnt receptor recruits Axin to the membrane, where Axin is somehow degraded. As a consequence, $\beta$-catenin is no longer bound by Axin, resulting in nuclear signaling by $\beta$-catenin. A separate study also reported that Wnt signaling causes a striking relocation of Drosophila Axin from the cytoplasm to the plasma membrane [16]. This relocation depends on Dvl and may permit the subsequent inactivation of the Axin complex by Wnt signaling. This LRP-mediated regulation of the Axin stability bypasses GSK-3 $\beta$, the kinase normally required for controlling $\beta$-catenin levels. This new finding argues for a different regulatory mechanism of Wnt signaling, proceeding through destruction of the negative regulator Axin rather than through the inhibition of the GSK-3 $\beta$ kinase activity. Consistent with the argument that the Axin stability is regulated are the observations that Axin is phosphorylated by GSK- $3 \beta$ and that the phosphorylated form is more stable than the unphosphorylated form [17]. However, it remains to be seen whether the regulatory role of phosphorylation by GSK- $3 \beta$ in Axin stability is actually modulated by LRP5/6.

\section{Axin Acts as a Scaffolding Protein to Coordinate $\beta$-Catenin Degradation in Wnt Signaling}

Based on yeast two-hybrid screenings, Axin was initially found to interact with GSK-3 $\beta$, $\beta$-catenin, and APC, forming a core multicomponent complex that governs cellular abundance of $\beta$-catenin $[8-10,38,45,74]$. In the Axin complex, $\beta$-catenin and GSK-3 $\beta$ bind adjacently within the central region of Axin. Axin proteins that lack the $\beta$-catenin- or GSK-3 $\beta$-binding regions fail to induce downregulation of $\beta$-catenin expression when overexpressed in SW480 cells. In PEL cells and KS tissue, LANA, a nuclear expressing protein with sequence homology to Axin GSK-3 $\beta$ binding site, stimulates the $\mathrm{S}$ phase relocalization of GSK-3 $\beta$, and this function requires its GSK-3 $\beta$-binding domain. Trapping of GSK-3 $\beta$ 
in the nucleus by LANA renders GSK-3 $\beta$ unable to bind Axin and $\beta$-catenin and to degrade $\beta$-catenin [80]. Thus, Axin was demonstrated to facilitate the interaction of $\beta$ catenin with GSK-3 $\beta$ and to act as a scaffold upon which related proteins assemble to coordinate the regulation of $\beta$-catenin levels for Wnt signaling. Upon Wnt activation, the Axin complex receives signals via LRP and Dvl, and the assembly of the complex is regulated to induce the dissociation of GSK-3 $\beta$ from the $\beta$-catenin degradation complex, presumably augmented by FRAT/GBP and CKI $\varepsilon$. Alternatively, Wnt signals lead to Axin translocation to the membrane, where Axin is degraded, so that $\beta$-catenin is not occupied by the Axin-based degradation complex and remains stable to manifest Wnt signaling in the nucleus.

\section{Axin in the JNK Pathway}

Mitogen-activated protein (MAP) kinases are instrumental in integrating numerous signals into biological processes, including embryogenesis, cell differentiation, cell proliferation, and cell death [122]. It is generally known that a MAP kinase cascade contains at least three components, namely MAP3K, MAPKK, and MAP kinase. A number of scaffold proteins for different MAP3Ks have been identified, including Ste 5p, JIPs, and MP1 [123]. It was demonstrated that Axin also exerts a function in the MAP kinase pathway. Overexpression of Axin in HEK293 cells leads to differential activation of MAP kinase, with robust induction for c-Jun NH2-terminal kinase $(\mathrm{JNK}) /$ stress-activated protein kinase, moderate induction for p38, and negligible induction for extracellular signal regulated kinase [18]. Determination of the functional domains of Axin reveals that domains utilized for the Wnt pathway are distinct from those for the JNK pathway. Domains essential in Wnt signaling, i.e., binding sites for APC, GSK-3 $\beta$, and $\beta$-catenin, are not required for JNK activation by Axin.

\section{Axin Binds to MEKK}

Axin seems to differ from those scaffold proteins such as JIP and MP1, in that it does not interact with either MKK4/7 or JNK directly. Rather, it interacts with and activates MEKK directly which in turn somehow activates MKK4/7 and then JNK. One of the most intriguing features of the Axin-mediated JNK activation is that it requires multiple other factors to enable the use of its multiple domains which differ from those used in the Wnt pathway to facilitate the activation of JNK.
Axin forms a complex with MEKK1, but not ASK1 or TAK1, through a domain termed MEKK1-interacting domain (MID) [18]. Axin without the MID domain has a dominant-negative effect on JNK activation by wild-type Axin. Both MKK4 and MKK7, which are downstream of MEKK1, are involved, as their dominant-negative forms can attenuate Axin-mediated JNK activation. The MID domain has been mapped to around aa 244-329, flanked by the binding sites for APC and GSK-3 $\beta[18,19]$. In addition, we have recently identified MEKK4 as a new Axin-binding protein that mediates Axin-induced JNK activation [19]. Dominant-negative MEKK4 diminishes Axin-mediated JNK activation. MEKK4 mediates Axin activation of JNK in the MEKK1-/- embryonic fibroblast cells. Surprisingly, MEKK4 and MEKK1 competes against each other for Axin binding, although MEKK4 binds to a region of aa 678-712 which is inside the PP2Abinding domain and distant from the MEKK1-binding site. Another domain between MEKK1- and MEKK4binding sites was also identified as being required for both MEKK1 and MEKK4 to activate JNK via Axin. Whereas removal of either the MEKK1-binding site or the MEKK4-binding site did not affect JNK activation by Axin, deletion of a small region encompassing aa 642673, N-terminal to the MEKK4-binding site, completely abolished Axin activation of JNK, although these mutants are intact in MEKK1 or MEKK4 binding. It remains an interesting issue as to how and why Axin-mediated JNK activation requires this region.

\section{Homodimerization Is Required for Axin-Mediated JNK Activation}

Another region of Axin essential for JNK activation is its C-terminal region, aa 507-832, in which the extreme C-terminal segment serves as a dimerization/oligomerization site [12]. It was found that Axin needs to be dimerized for JNK activation, although MEKK is capable of binding C-terminus-deleted monomeric Axin [18]. Consistently, Dvl heterodimeric interaction with Axin can also abolish JNK activation by Axin. Axin with the MEKK1-binding domain deleted could prevent wild-type Axin from activating JNK, indicating that Axin requires MEKK1 to assume a dimeric configuration which may be an important feature of MEKK activation in the Axin/ JNK pathway. It is equally possible that Axin dimerization is required for recruitment of other factors to activate MEKK.

\footnotetext{
$\overline{108} \quad \overline{\text { Neurosignals 2004;13:99-113 }}$
} 


\section{Participation of Sumoylating Enzyme PIAS Proteins} in the Axin/JNK Pathway

The Axin C-terminal region also exerts its role in JNK activation in another way. It was recently found that Axin interacts with three SUMO-1 (small ubiquitin-related modifier) conjugating enzymes 3 (E3), PIAS1, PIASxb, and PIASy, by a yeast two-hybrid screen using the extreme C-terminal 145-aa region of Axin as bait [27]. The extreme C-terminal six amino acid residues (KVEKVD) of Axin are identified as two contiguous sumoylation sites. Sumoylation represents one of the most important posttranslational modifications, modulating a wide spectrum of proteins that participate in protein translocation, transcriptional regulation, signal transduction, and cell growth control [24, 123-128]. It was discovered that Axin is a heavily sumoylated protein at the C-terminal end. Interestingly, removal of either of the two sites diminished JNK activation by Axin. Removal of both of the sites (Axin $\Delta \mathrm{C} 6$ ) rendered Axin virtually to have no JNKactivating activity, but has no effect on its ability to effectively destabilize $\beta$-catenin and attenuate LEF 1 transcriptional activity. Loss of the JNK-activating ability in Axin $\Delta \mathrm{C} 6$ is not caused by its failure to form homodimer or to bind to MEKK. It is unclear how sumoylation plays a role in the Axin-induced JNK activation. Possibly, sumoylation helps to regulate protein-protein interactions among the many factors that participate with MEKK to activate JNK. It is interesting to note that both PIAS and Axin are capable of activating JNK and causing apoptosis in a JNK-dependent manner. Remarkably, Axin mutants act dominant negatively on the PIAS-mediated JNK activation. Therefore, PIAS acts either upstream or at a position parallel to Axin [27].

Thus, multiple domains, including MEKK1- and MEKK4-binding sites, DIX domain, the extreme C-terminal six amino acids, and an unnamed domain flanked by the $\beta$-catenin-binding site and the MEKK4-binding site, are found at present to be required for JNK activation by Axin. How these factors coordinate to mediate JNK activation via Axin remains unclear.

\section{Inhibition of Axin-Mediated JNK Activation by Wnt}

Components

In addition to inhibition of Axin activation by Dvl due to disruption of homodimerization, other components in the Wnt pathway also attenuate JNK activation by Axin. These include GSK-3b, CKI $\alpha$, and CKI $\varepsilon$. It was shown

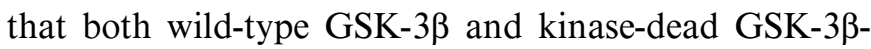
Y216F (capable of binding to Axin), but not GSK-3 $\beta$ $\mathrm{K} 85 \mathrm{M}$ (incapable of binding to Axin in mammalian cells), prevented MEKK1 binding to the Axin complex, thereby inhibiting JNK activation [24]. Similarly, CKIs also inhibited Axin-mediated JNK activation by competing against MEKK1 binding [24]. In contrast, $\beta$-catenin and APC binding did not affect MEKK1 binding to the same Axin complex, indicating that MEKK1, $\beta$-catenin, and APC can be copresent in the same Axin complex. These observations suggest that even when Axin is 'switched' to activate the JNK pathway, it is still capable of sequestering free $\beta$-catenin which is a critical aspect for cellular homeostasis. The above studies also indicate that there exist differential molecular assemblies on Axin between the Wnt pathway and the Axin/JNK pathway. The extracellular or cellular factors that modulate the distinct complex formations remain to be elucidated. More pressing tasks are to identify the biological function of the Axin/ JNK pathway.

\section{Axin in Other Signaling Pathways}

The number of Axin-interacting proteins seems to be ever enlarging. Axin also regulates the effects of Smad3 in the transforming growth factor beta (TGF- $\beta$ ) signaling pathway and functions as an adaptor for $\operatorname{Smad} 3$, facilitating its activation by TGF- $\beta$ receptors for efficient TGF- $\beta$ signaling [23]. In the absence of activated TGF- $\beta$ receptors, Axin physically interacted with Smad3 through its C-terminal region located between the $\beta$-catenin-binding site and DIX domain. Axin2 also interacted with Smad3. In the absence of ligand stimulation, Axin was colocalized with Smad3 in the cytoplasm in vivo. Upon receptor activation, Smad 3 was strongly phosphorylated by TGF- $\beta$ type I receptor in the presence of Axin and dissociated from TGF- $\beta$ type I receptor and Axin. It will be of great interest to elucidate the functional roles of Axin in TGF- $\beta$ signaling in animals, given that TGF- $\beta$ signaling is known to play important roles in development [129].

Eph receptors and ephrins exhibit a unique mode of signaling in that each molecule can function as both a ligand capable of sending signals and a receptor capable of transducing signals $[130,131]$. In a modified yeast twohybrid screen that allows for the detection of protein-protein interactions involving phosphotyrosine, using a murine neonatal brain complementary DNA library, the $\mathrm{SH} 2 / 3$ domain adaptor protein Grb4 was identified to interact with the ephrin-B1 cytoplasmic domain in a phosphotyrosine-dependent manner. Grb4 uses its $\mathrm{SH} 2$ domain to bind to ephrin-B1 and associates with the reverse signaling of the bidirectional signals that are trans- 
duced by Eph receptors and ephrins. Interestingly, the $\mathrm{SH} 3$ domain of Grb4 was demonstrated to interact with Axin in another yeast two-hybrid screening [22]. The Eph/ ephrin signals are thought to control cell and axon growthcone movement by repulsion, presumably by inducing changes in the cytoskeleton. The DIX domain that is conserved in Axin, Dvl, and Ccd1 was demonstrated to mediate targeting to actin stress fibers and cytoplasmic vesicles [64]. It remains to be seen whether Axin can link Eph/ephrin signaling to the actin cytoskeleton.

Perhaps the most surprising Axin partner is the CAP protein, a component in the signaling pathway required for insulin-dependent glucose transport [132]. In a yeast two-hybrid screen using the Drosophila Axin protein as bait, Axin was found to interact with D-CAP that harbors an $\mathrm{SH} 3$ domain at the $\mathrm{C}$ terminus. Knockdown of Axin by RNAi in S2 cells results in increased accumulation of glycogen, suggesting that Axin enhances glycogen decomposition and possibly that there is a cross talk between Wnt signaling and insulin signaling [133].

\section{Concluding Remarks}

Since its initial cloning, Axin has turned out to be a remarkable protein that exerts a pleiotropic scaffolding role. Clearly, it serves as a central platform for the APCGSK-3 $\beta-\beta$-catenin-CK- $\beta$-catenin degradation complex as well as a major scaffold for the JNK pathway. In the light of the fact that Axin interacts with multiple proteins that participate in different signaling pathways besides the Wnt pathway, it could mediate cross talks among diverse signaling pathways that play critical roles in cell fate decision and suppression of tumorigenesis. In fact, from the evidence we have thus far gathered, Axin controls biological processes ranging from sugar intake, cell proliferation, and organ development to cell death. It would not be surprising that we will find yet more roles of Axin, both biochemical and biological.

\section{References}

1 Wodarz A, Nusse R: Mechanisms of Wnt signaling in development. Annu Rev Cell Dev Biol 1998; 14:59-88

2 Pandur P, Maurus D, Kuhl M: Increasingly complex: New players enter the Wnt signaling network. Bioessays 2002;24:881-884.

3 Mao J, Wang J, Liu B, Pan W, Farr GH 3rd, Flynn C, Yuan H, Takada S, Kimelman D, Li $\mathrm{L}, \mathrm{Wu} \mathrm{D}$ : Low-density lipoprotein receptorrelated protein-5 binds to Axin and regulates the canonical Wnt signaling pathway. Mol Cell 2001;7:801-809.

4 Wehrli M, Dougan ST, Caldwell K, O'Keefe L, Schwartz S, Vaizel D: arrow encodes an LDLreceptor-related protein essential for Wingless signaling. Nature 2000;407:527-530.

5 Tolwinski NS, Wehrli M, Rives A, Erdeniz N, DiNardo S, Wieschaus E: Wg/Wnt signal can be transmitted through arrow/LRP5,6 and Axin independently of Zw3/GSK-3 $\beta$ activity. Dev Cell 2003;4:407-418.

6 Kishida S, Yamamoto H, Hino S, Ikeda M, Kishida M, Kikuchi A: DIX domains of Dvl and Axin are necessary for protein interactions and their ability to regulate $\beta$-catenin stability. Mol Cell Biol 1999;19:4414-4422.

7 Li L, Yuan H, Weaver CD, Mao J, Farr GH, Sussman DJ, Jonkers J, Kimelman D, Wu D: Axin and Fratl interact with Dvl and GSK, bridging Dvl to GSK in Wnt-mediated regulation of LEF-1. EMBO J 1999; 18:4233-4240.
8 Kishida S, Yamamoto H, Ikeda S, Kishida M, Sakamoto I, Koyama S, Kikuchi A: Axin, a negative regulator of the wnt signaling pathway, directly interacts with adenomatous polyposis coli and regulates the stabilization of $\beta$ catenin. J Biol Chem 1998;273:10823-10826.

9 Hart MJ, de los Santos R, Albert IN, Rubinfeld B, Polakis P: Downregulation of $\beta$-catenin by human Axin and its association with the APC tumor suppressor, $\beta$-catenin and GSK-3 $\beta$. Curr Biol 1998;8:573-581.

10 Nakamura T, Hamada F, Ishidate T, Anai K, Kawahara K, Toyoshima K, Akiyama T: Axin, an inhibitor of the Wnt signaling pathway, interacts with $\beta$-catenin, GSK-3 $\beta$ and APC and reduces the $\beta$-catenin level. Genes Cells 1998; 3:395-403.

11 Rubinfeld B, Tice DA, Polakis P: Axin-dependent phosphorylation of the adenomatous polyposis coli protein mediated by casein kinase I $\varepsilon$. J Biol Chem 2001;276:39037-39045.

12 Hsu W, Zeng L, Costantini F: Identification of a domain of Axin that binds to the serine/ threonine protein phosphatase $2 \mathrm{~A}$ and a selfbinding domain. J Biol Chem 1999;274:3439_ 3445 .

13 Schwarz-Romond T, Asbrand C, Bakkers J, Kuhl M, Schaeffer HJ, Huelsken J, Behrens J, Hammerschmidt M, Birchmeier W: The ankyrin repeat protein diversin recruits casein kinase $\mathrm{I} \varepsilon$ to the $\beta$-catenin degradation complex and acts in both canonical Wnt and Wnt/JNK signaling. Genes Dev 2002;16:2073-2084.
14 Shiomi K, Uchida H, Keino-Masu K, Masu M: Ccd1, a novel protein with a DIX domain, is a positive regulator in the Wnt signaling during zebrafish neural patterning. Curr Biol 2003;13: 73-77.

15 Kadoya T, Kishida S, Fukui A, Hinoi T, Michiue T, Asashima M, Kikuchi A: Inhibition of Wnt signaling pathway by a novel Axin-binding protein. J Biol Chem 2000;275:3703037037.

16 Cliffe A, Hamada F, Bienz M: A role of Dishevelled in relocating axin to the plasma membrane during wingless signaling. Curr Biol 2003;13:960-966.

17 Yamamoto H, Kishida S, Kishida M, Ikeda S, Takada S, Kikuchi A: Phosphorylation of axin, a Wnt signal negative regulator, by glycogen synthase kinase- $3 \beta$ regulates its stability. J Biol Chem 1999;274:10681-10684.

18 Zhang Y, Neo SY, Wang X, Han J, Lin SC: Axin forms a complex with MEKK1 and activates c-Jun $\mathrm{NH}(2)$-terminal kinase/stress-activated protein kinase through domains distinct from Wnt signaling. J Biol Chem 1999;274: 35247-35254.

19 Luo W, Ng WW, Jin LH, Ye Z, Han J, Lin SC: Axin utilizes distinct regions for competitive MEKK1 and MEKK4 binding and JNK activation. J Biol Chem 2003;278:37451-37458. 
20 Kusano S, Raab-Traub N: I-mfa domain proteins interact with Axin and affect its regulation of the Wnt and c-Jun N-terminal kinase signaling pathways. Mol Cell Biol 2002;22: 6393-6405.

21 Yamazaki $H$, Nusse R: Identification of DCAP, a Drosophila homolog of a glucose transport regulatory complex. Mech Dev 2002; 119:115-119.

22 Cowan CA, Henkemeyer M: The SH2/SH3 adaptor Grb4 transduces B-ephrin reverse signals. Nature 2001:413:174-179.

23 Furuhashi M, Yagi K, Yamamoto H, Furukawa Y, Shimada S, Nakamura Y, Kikuchi A, Miyazono K, Kato M: Axin facilitates Smad3 activation in the transforming growth factor beta signaling pathway. Mol Cell Biol 2001;21: 5132-5141.

24 Zhang Y, Qiu WJ, Liu DX, Neo SY, He X, Lin SC: Differential molecular assemblies underlie the dual function of Axin in modulating the Wnt and JNK pathways. J Biol Chem 2001; 276:32152-32159.

25 Zhang Y, Neo SY, Han J, Lin SC: Dimerization choices control the ability of Axin and dishevelled to activate c-Jun N-terminal kinase/ stress-activated protein kinase. J Biol Chem 2000;275:25008-25014

26 Zhang Y, Qiu WJ, Chan SC, Han J, He X, Lin SC: Casein kinase I and casein kinase II differentially regulate Axin function in Wnt and JNK pathways. J Biol Chem 2002;277:1770617712.

27 Rui HL, Fan E, Zhou HM, Xu Z, Zhang Y, Lin SC: SUMO-1 modification of the C-terminal KVEKVD of Axin is required for JNK activation but has no effect on Wnt signaling. J Biol Chem 2002;277:42981-42986.

28 Zeng L, Fagotto F, Zhang T, Hsu W, Vasicek TJ, Perry WL, Lee JJ, Tilghman SM, Gumbiner BM, Costantini F: The mouse Fused locus encodes Axin, an inhibitor of the Wnt signaling pathway that regulates embryonic axis formation. Cell 1997;90:181-192.

29 Lyon MF, Rastan S, Brown SD: Genetic Variants and Strains of the Laboratory Mouse. Oxford, Oxford University Press, 1996.

30 Ruvinsky A, Flood WD, Zhang T, Costantini F: Unusual inheritance of the Axin Fu mutation in mice is associated with widespread rearrangements in the proximal region of chromosome 17. Genet Res 2000;76:135-147.

31 Vasicek TJ, Zeng L, Guan XJ, Zhang T, Costantini F, Tilghman SM: Two dominant mutations in the mouse fused gene are the result of transposon insertions. Genetics 1997;147:777786.

32 Rakyan VK, Chong S, Champ ME, Cuthbert PC, Morgan HD, Luu KV, Whitelaw E: Transgenerational inheritance of epigenetic states at the murine Axin ${ }^{\mathrm{Fu}}$ allele occurs after maternal and paternal transmission. Proc Natl Acad Sci USA 2003; 100:2538-2543.

33 Gluecksohn-Schoenheimer S: The effects of a lethal mutation responsible for duplications and twinning in mouse embryos. $\mathbf{J}$ Exp Zool 1949;110:47-76.
34 Jacobs-Cohen RJ, Spiegelman M, Cookingham JC, Bennett D: Knobbly, a new dominant mutation in the mouse that affects embryonic ectoderm organization. Genet Res 1984;43: 43-50.

35 Perry WL, Vasicek TJ, Lee JJ, Rossi JM, Zeng L, Zhang T, Tilghman SM, Costantini F: Phenotypic and molecular analysis of a transgenic insertional allele of the mouse Fused locus. Genetics 1995;141:321-332.

36 Druey KM, Blumer KJ, Kang VH, Kehrl JH: Inhibition of G-protein-mediated MAP kinase activation by a new mammalian gene family. Nature 1996;379:742-746.

37 Burchett SA: Regulators of $G$ protein signaling: A bestiary of modular protein binding domains. J Neurochem 2000;75:1335-1351.

38 Ikeda S, Kishida S, Yamamoto H, Murai H, Koyama S, Kikuchi A: Axin, a negative regulator of the Wnt signaling pathway, forms a complex with GSK- $3 \beta$ and $\beta$-catenin and promotes GSK-3 $\beta$-dependent phosphorylation of $\beta$-catenin. EMBO J 1998;17:1371-1384.

39 Yamamoto H, Kishida S, Uochi T, Ikeda S, Koyama S, Asashima M, Kikuchi A: Axil, a member of the Axin family, interacts with both glycogen synthase kinase 3 beta and beta-catenin and inhibits axis formation of Xenopus embryos. Mol Cell Biol 1998;18:2867-2875.

40 Behrens J, Jerchow BA, Wurele M, Grimm J, Asbrand C, Wirtz R, Kuhl M, Wedlich D, Birchmeier W: Functional interaction of an axin homolog, conductin, with $\beta$-catenin, APC, and GSK3 $\beta$. Science 1998;280:596-599.

41 Hedgepeth CM, Deardorff MA, Klein PS: Xenopus axin interacts with glycogen synthase kinase- $3 \beta$ and is expressed in the anterior midbrain. Mech Dev 1999;80:147-151.

42 Hamada F, Tomoyasu Y, Takatsu Y, Nakamura M, Nagai S, Suzuki A, Fujita F, Shibuya $H$, Toyoshima K, Ueno N, Akiyama T: Negative regulation of Wingless signaling by $\mathrm{D}$-axin, a Drosophila homolog of axin. Science 1999;283: 1739-1742.

43 Korswagen HC, Coudreuse DY, Betist MC, van de Water S, Zivkovic D, Clevers HC: The Axin-like protein PRY-1 is a negative regulator of a canonical Wnt pathway in C. elegans. Genes Dev 2002;16:1291-1302.

44 Peifer M, Polakis P: Wnt signaling in oncogenesis and embryogenesis - a look outside the nucleus. Science 2000;287:1606-1609.

45 Sakanaka C, Weiss JB, Williams LT: Bridging of $\beta$-catenin and glycogen synthase kinase- $3 \beta$ by axin and inhibition of $\beta$-catenin-mediated transcription. Proc Natl Acad Sci USA 1998; 95:3020-3023.

46 Fagotto F, Jho E, Zeng L, Kurth T, Joos T, Kaufmann C, Costantini F: Domains of axin involved in protein-protein interactions, Wnt pathway inhibition, and intracellular localization. J Cell Biol 1999;145:741-756.

47 Willert K, Logan CY, Arora A, Fish M, Nusse R: A Drosophila Axin homolog, Daxin, inhibits Wnt signaling. Development 1999;126:41654173.
48 Farr GH 3rd, Ferkey DM, Yost C, Pierce SB, Weaver C, Kimelman D: Interaction among GSK-3, GBP, axin, and APC in Xenopus axis specification. J Cell Biol 2000;148:691-702.

49 Satoh S, Daigo Y, Furukawa Y, Kato T, Miwa N, Nishiwaki T, Kawasoe T, Ishiguro H, Fujita M, Tokino T: AXIN1 mutations in hepatocellular carcinomas and growth suppression in cancer cells by virus-mediated transfer of AXIN1. Nat Genet 2000;24:245-250.

50 Miao J, Kusafuka T, Udatsu Y, Okada A: Sequence variants of the Axin gene in hepatoblastoma. Hepatol Res 2003;25:174-179.

51 Taniguchi K, Roberts LR, Aderca IN, Dong X, Qian C, Murphy LM, Nagorney DM, Burgart LJ, Roche PC, Smith DI, Ross JA, Liu W: Mutational spectrum of $\beta$-catenin, AXIN1, and AXIN2 in hepatocellular carcinomas and hepatoblastomas. Oncogene 2002;31:4863-4871.

52 Neo SY, Zhang Y, Yaw LP, Li P, Lin SC: Axininduced apoptosis depends on the extent of its JNK activation and its ability to down-regulate $\beta$-catenin levels. Biochem Biophys Res Commun 2000;272:144-150.

53 Hsu W, Shakya R, Costantini F: Impaired mammary gland and lymphoid development caused by inducible expression of Axin in transgenic mice. J Cell Biol 2001;155:10551064

54 Webster MT, Rozycka M, Sara E, Davis E, Smalley M, Young N, Dale TC, Wooster R: Sequence variants of the axin gene in breast, colon, and other cancers: An analysis of mutations that interfere with GSK 3 binding. Genes Chromosomes Cancer 2000;28:443-453.

55 Yokota N, Nishizawa S, Ohta S, Date H, Sugimura H, Namba H, Maekawa M: Role of Wnt pathway in medulloblastoma oncogenesis. Int J Cancer 2002;101:198-201.

56 Dahmen RP, Koch A, Denkhaus D, Tonn JC, Sorensen N, Berthold F, Behrens J, Birchmeier $\mathrm{W}$, Wiestler OD, Pietsch T: Deletions of AXIN1, a component of the WNT/wingless pathway, in sporadic medulloblastomas. Cancer Res 2001;61:7039-7043.

57 Baeza N, Masuoka J, Kleihues P, Ohgaki H: AXIN1 mutants but not deletions in cerebellar medulloblastomas. Oncogene 2003;22:632636.

58 Jin LH, Shao QJ, Luo W, Ye ZY, Li Q, Lin SC: Detection of point mutations of the Axin 1 gene in colorectal cancers. Int J Cancer 2003;107: 696-699.

59 Habas R, Kato Y, He X: Wnt/Frizzled activation of Rho regulates vertebrate gastrulation and requires a novel Formin homology protein, Daam 1. Cell 2001;107:843-854.

60 Tada M, Smith JC: Xwnt 11 is a target of Xenopus Brachyury: Regulation of gastrulation movements via Dishevelled, but not through the canonical Wnt pathway. Development 2000;127:2227-2238.

61 Wallingford JB, Rowning BA, Vögeli KM, Rothbacher U, Fraser SE, Harland RM: Dishevelled controls cell polarity during Xenopus gastrulation. Nature 2000;405:81-85. 
62 Gho M, Schweisguth F: Frizzled signalling controls orientation of asymmetric sense organ precursor cell divisions in Drosophila. Nature 1998;393:178-181.

63 Cadigan KM, Nusse R: Wnt signaling: A common theme in animal development. Genes Dev 1997; 11:3286-3305.

64 Capelluto DG, Kutateladze TG, Habas R, Finkielstein $\mathrm{CV}$, He X, Overduin M: The DIX domain targets dishevelled to actin stress fibres and vesicular membranes. Nature 2002;419: 726-729.

65 Christian JL, Moon RT: Interactions between Xwnt-8 and Spemann organizer signaling pathways generate dorsoventral pattern in the embryonic mesoderm of Xenopus. Genes Dev 1993;7:13-28.

66 Greenspan RJ, O'Brien MC: Genetic analysis of mutations at the fused locus in the mouse. Proc Natl Acad Sci USA 1986;83:4413-4417.

67 Spink KE, Polakis P, Weis WI: Structural basis of the axin-adenomatous polyposis coli interaction. EMBO J 2000; 19:2270-2279.

68 Rosin-Arbesfeld R, Cliffe A, Brabletz T, Bienz $\mathrm{M}$ : Nuclear export of the APC tumor suppressor controls beta-catenin function in transcription. EMBO J 2003;22:1101-1113.

69 Henderson BR, Fagotto F: The ins and outs of APC and beta-catenin nuclear transport. EMBO Rep 2002;3:834-839.

70 Ahmed Y, Hayashi S, Levine A, Wieschaus E: Regulation of armadillo by a Drosophila APC inhibits neuronal apoptosis during retinal development. Cell 1998;93:1171-1182

71 Hinoi T, Yamamoto H, Kishida M, Takada S, Kishida S, Kikuchi A: Complex formation of adenomatous polyposis coli gene product and axin facilitates glycogen synthase kinase- $3 \beta$ dependent phosphorylation of beta-catenin and down-regulates beta-catenin. J Biol Chem 2000;275:34399-34406.

72 Kawahara K, Morishita T, Nakamura T, Hamada F, Toyoshima K, Akiyama T: Down-regulation of beta-catenin by the colorectal tumor suppressor APC requires association with Axin and $\beta$-catenin. J Biol Chem 2000;275:8369_ 8374.

73 Rubinfeld B, Albert I, Porfiri E, Munemitsu S Polakis P: Loss of beta-catenin regulation by the APC tumor suppressor protein correlates with loss of structure due to common somatic mutations of the gene. Cancer Res 1997;57: 4624-4630.

74 Itoh K, Krupnik VE, Sokol SY: Axis determination in Xenopus involves biochemical interactions of axin, glycogen synthase kinase 3 and $\beta$-catenin. Curr Biol 1998;8:591-594.

75 Ding Y, Dale T: Wnt signal transduction: Kinase cogs in a nano-machine? Trends Biochem Sci 2002;27:327-329.

76 Dajani R, Fraser E, Roe SM, Yeo M, Good VM, Thompson V, Dale TC, Pearl LH: Structural basis for recruitment of glycogen synthase kinase $3 \beta$ to the axin-APC scaffold complex. EMBO J 2003;22:494-501.
77 Plyte SE, Hughes K, Nikolakaki E, Pulverer BJ, Woodgett JR: Glycogen synthase kinase-3: Functions in oncogenesis and development. Biochim Biophys Acta 1992;1114:147-162.

78 Mandelkow EM, Drewes G, Biernat J, Gustke N, Van Lint J, Vandenheede JR, Mandelkow E: Glycogen synthase kinase- 3 and the Alzheimer-like state of microtubule-associated protein tau. FEBS Lett 1992;314:315-321.

79 Rubinfeld B, Albert I, Porfiri E, Fiol C, Munemitsu S, Polakis P: Binding of GSK-3 $\beta$ to the APC- $\beta$-catenin complex and regulation of complex assembly. Science 1996;272:1023-1026.

80 Fujimuro M, Wu FY, ApRhys C, Kajumbula H, Young DB, Hayward GS, Hayward SD: A novel viral mechanism for dysregulation of $\beta$ catenin in Kaposi's sarcoma-associated herpesvirus latency. Nat Med 2003;9:300-306.

81 Liu C, Li Y, Semenov M, Han C, Baeg GH, Tan Y, Zhang Z, Lin X, He X: Control of betacatenin phosphorylation/degradation by a dual-kinase mechanism. Cell 2002;108:837847.

82 Gumbiner BM, McCrea PD: Catenins as mediators of the cytoplasmic functions of cadherins. J Cell Sci Suppl 1993;17:155-158.

83 Schneider S, Herrenknecht K, Butz S, Kemler $\mathrm{R}$, Hausen P: Catenins in Xenopus embryogenesis and their relation to the cadherin-mediated cell-cell adhesion system. Development 1993; 118:629-640.

84 Gottardi CJ, Gumbiner BM: Adhesion signaling: How $\beta$-catenin interacts with its partners. Curr Biol 2001;11:R792-R794.

85 Behrens J, von Kries JP, Kuhl M, Bruhn L, Wedlich D, Grosschedl R, Birchmeier W: Functional interaction of beta-catenin with the transcription factor LEF-1. Nature 1996;382: 638-642.

86 Gumbiner BM: Signal transduction of betacatenin. Curr Opin Cell Biol 1995;7:634-640.

87 Peifer M, Orsulic S, Pai LM, Loureiro J: A model system for cell adhesion and signal transduction in Drosophila. Dev Suppl 1993: 163-176.

88 Papkoff J, Rubinfeld B, Schryver B, Polakis P: Wnt-1 regulates free pools of catenins and stabilizes APC-catenin complexes. Mol Cell Biol 1996;16:2128-2134.

89 Peifer M, Sweeton D, Casey M, Wieschaus E: Wingless signal and Zeste-white 3 kinase trigger opposing changes in the intracellular distribution of Armadillo. Development 1994;120: 369-380.

90 Aberle HA, Bauer A, Stappert J, Kispert A, Kemler R: $\beta$-Catenin is a target for the ubiquitin-proteasome pathway. EMBO J 1997;16: 3797-3804.

91 Brannon M, Gomperts M, Sumoy L, Moon RT, Kimelman D: A $\beta$-catenin/XTcf-3 complex binds to the siamois promoter to regulate dorsal axis specification in Xenopus. Genes Dev 1997;11:2359-2370.

92 Laurent MN, Blitz IL, Hashimoto C, Rothbacher U, Cho KW: The Xenopus homeobox gene twin mediates Wnt induction of goosecoid in establishment of Spemann's organizer. Development 1997;124:4905-4916.
93 Molenaar M, van de Wetering M, Oosterwegel M, Peterson-Maduro J, Godsave S, Korinek V, Roose J, Destree O, Clevers H: XTcf-3 transcription factor mediates beta-catenin-induced axis formation in Xenopus embryos. Cell 1996;86:391-399.

94 McKendry R, Hsu SC, Harland RM, Grosschedl R: LEF-1/TCF proteins mediate wntinducible transcription from the Xenopus nodal-related 3 promoter. Dev Biol 1997;192: 420-431.

95 Tetsu O, McCormick F: Beta-catenin regulates expression of cyclin D1 in colon carcinoma cells. Nature 1999;398:422-426.

96 He TC, Sparks AB, Rago C, Hermeking H, Zawel L, da Costa LT, Morin PJ, Vogelstein $\mathrm{B}$, Kinzler KW: Identification of c-MYC as a target of the APC pathway. Science 1998;281: 1509-1512.

97 Seeling JM, Miller JR, Gil R, Moon RT, White R, Virshup DM: Regulation of $\beta$-catenin signaling by the B56 subunit of protein phosphatase 2A. Science 1999;283:20892091.

98 Ikeda S, Kishida M, Matsuura Y, Usui H, Kikuchi A: GSK-3ß-dependent phosphorylation of adenomatous polyposis coli gene product can be modulated by $\beta$-catenin and protein phosphatase $2 \mathrm{~A}$ complexed with Axin. Oncogene 2000; 19:537-545.

99 Ratcliffe MJ, Itoh K, Sokol SY: A positive role for the PP2A catalytic subunit in Wnt signal transduction. J Biol Chem 2000;275: 35680-35683.

100 Yamamoto H, Hinoi T, Michiue T, Fukui A, Usui H, Janssens V, Van Hoof C, Goris J, Asashima M, Kikuchi A: Inhibition of the Wnt signaling pathway by the PR61 subunit of protein phosphatase 2A. J Biol Chem 2001; 276:26875-26882.

101 Li X, Yost HJ, Virshup DM, Seeling JM: Protein phosphatase 2A and its B56 regulatory subunit inhibit Wnt signaling in Xenopus. EMBO J 2001;20:4122-4131.

102 Rubinfeld B, Souza B, Albert I, Muller O, Chamberlain SH, Masiarz FR, Munemitsu S, Polakis P: Association of the APC gene product with beta-catenin. Science 1993;262: 1731-1734.

103 Fish KJ, Cegielska A, Getman ME, Landes GM, Virshup DM: Isolation and characterization of human casein kinase I epsilon (CKIE), a novel member of the CKI gene family. J Biol Chem 1995;270:14875-14883.

104 Vielhaber E, Eide E, Rivers A, Gao ZH, Virshup DM: Nuclear entry of the circadian regulator mPER 1 is controlled by mammalian casein kinase I epsilon. Mol Cell Biol 2000; 20:4888-4899.

105 Lowrey PL, Shimomura K, Antoch MP, Yamazaki S, Zemenides PD, Ralph MR, Menaker M, Takahashi JS: Positional syntenic cloning and functional characterization of the mammalian circadian mutation tau. Science 2000;288:483-492.

106 Polakis P: Casein kinase 1: A Wnt'er of disconnect. Curr Biol 2002;12:R499-R501. 
107 Peters JM, McKay RM, McKay JP, Graff JM: Casein kinase I transduces Wnt signals. Nature 1999;401:345-350.

108 Sakanaka C, Leong P, Xu L, Harrison SD, Williams LT: Casein kinase Iepsilon in the Wnt pathway: Regulation of $\beta$-catenin function. Proc Natl Acad Sci USA 1999;96: 12548-12552.

109 Gao ZH, Seeling JM, Hill V, Yochum A, Virshup DM: Casein kinase I phosphorylates and destabilizes the $\beta$-catenin degradation complex. Proc Natl Acad Sci USA 2002;99:11821187.

110 Hino S, Michiue T, Asashima M, Kikuchi A Casein kinase I epsilon enhances the binding of Dvl-1 to Frat-1 and is essential for Wnt3a-induced accumulation of beta-catenin. $\mathrm{J}$ Biol Chem 2003;278:14066-14073.

111 Polakis P: Wnt signaling and cancer. Genes Dev 2000;14:1837-1851.

112 Amit S, Hatzubai A, Birman Y, Andersen JS, Ben-Shushan E, Mann M, Ben-Neriah Y, Alkalay I: Axin-mediated CKI phosphorylation of $\beta$-catenin at Ser 45: A molecular switch for the Wnt pathway. Genes Dev 2002; 16:10661076.

113 Sussman DJ, Klingensmith J, Salinas P, Adams PS, Nusse R, Perrimon N: Isolation and characterization of a mouse homolog of the Drosophila segment polarity gene dishevelled. Dev Biol 1994;166:73-86.

114 Willert K, Brink M, Wodarz A, Varmus H, Nusse R: Casein kinase 2 associates with and phosphorylates dishevelled. EMBO J 1997; 16:3089-3096.

115 Jonkers J, Korswagen HC, Acton D, Breuer M, Berns A: Activation of a novel proto-oncogene, Frat1, contributes to progression of mouse T-cell lymphomas. EMBO J 1997;16: 441-450.
116 Kadoya T, Yamamoto H, Suzuki T, Yukita A, Fukui A, Michiue T, Asahara T, Tanaka K, Asashima M, Kikuchi A: Desumoylation activity of Axam, a novel Axin-binding protein, is involved in downregulation of $\beta$-catenin. Mol Cell Biol 2002;22:3803-3819.

117 Yamamoto H, Ihara M, Matsuura Y, Kikuchi A: Sumoylation is involved in $\beta$-catenin-dependent activation of Tcf-4. EMBO J 2003; 22:2047-2059.

118 Herz J, Strickland DK: LRP: A multifunctional scavenger and signaling receptor. J Clin Invest 2001;108:779-784.

119 Pinson KI, Brennan J, Monkley S, Avery BJ, Skarnes WC: An LDL-receptor-related protein mediates Wnt signaling in mice. Nature 2000;407:535-538.

120 Tamai K, Semenov M, Kato Y, Spokony R, Liu C, Katsuyama Y, Hess F, Saint-Jeannet JP, He X: LDL-receptor-related proteins in Wnt signal transduction. Nature 2000;407: 530-535.

121 Semenov MV, Tamai K, Brott BK, Kuhl M, Sokol S, He X: Head inducer Dickkopf-1 is a ligand for Wnt coreceptor LRP6. Curr Biol 2001;11:951-961.

122 Johnson GL, Lapadat R: Mitogen-activated protein kinase pathways mediated by ERK, JNK, and p38 protein kinases. Science 2002; 298:1911-1912.

123 Hagemann C, Blank JL: The ups and downs of MEK kinase interactions. Cell Signal 2001; 13:863-875.

124 Schmidt D, Müller S: Members of the PIAS family act as SUMO ligases for c-Jun and p53 and repress p53 activity. Proc Natl Acad Sci USA 2002;99:2872-2877.
125 Müller S, Hoege C, Pyrowolakis G, Jentsch S: SUMO, ubiquitin's mysterious cousin. Nat Rev Mol Cell Biol 2001;2:202-210.

126 Kwek SS, Derry J, Tyner AL, Shen Z, Gudkov AV: Functional analysis and intracellular localization of p53 modified by SUMO-1. Oncogene 2001;20:2587-2599.

127 Melchior F, Hengst L: SUMO-1 and p53. Cell Cycle 2002;1:245-249.

128 Verger A, Perdomo J, Crossley M: Modification with SUMO: A role in transcriptional regulation. EMBO Rep 2003;4:137-142.

129 Pepper MS: Transforming growth factor-beta: Vasculogenesis, angiogenesis, and vessel wall integrity. Cytokine Growth Factor Rev 1997; 8:21-43.

130 Henkemeyer M, Orioli D, Henderson JT, Saxton TM, Roder J, Pawson T, Klein R: Nuk controls pathfinding of commissural axons in the mammalian central nervous system. Cell 1996;86:35-46.

131 Birgbauer E, Cowan CA, Sretavan DW, Henkemeyer M: Kinase independent function of EphB receptors in retinal axon pathfinding to the optic disc from dorsal but not ventral retina. Development 2000;127:1231-1241.

132 Baumann CA, Ribon V, Kanzaki M, Thurmond DC, Mora S, Shigematsu S, Bickel PE, Pessin JE, Saltiel AR: CAP defines a second signaling pathway required for insulin-stimulated glucose transport. Nature 2000;407: 202-207.

133 Yamazaki H, Yanagawa S: Axin and Axin/ Arrow-binding protein DCAP mediate glucose-glycogen metabolism. Biochem Biophys Res Commun 2003;304:229-235. 